\title{
Improving the Shelf Life of Peeled Fresh Almond Kernels by Edible Coating with Mastic Gum
}

\author{
Muhammad Farooq ${ }^{1,+}$, Elham Azadfar ${ }^{2,+}$, Alexandru Rusu ${ }^{3, *}$, Monica Trif ${ }^{4, *}\left(\mathbb{C}\right.$, Mahmoud Kohneh Poushi ${ }^{5}$ \\ and Yunyang Wang ${ }^{1, *}$ \\ 1 College of Food Science and Engineering, Northwest A\&F University, Yangling 712100, China; \\ farooq.fst28@gmail.com \\ 2 Young Researchers, and Elites Club, Sabzevar Branch, Islamic Azad University, Sabzevar 96187-35133, Iran; \\ elham_az1313@yahoo.com \\ 3 Research and Development, CENCIRA Agrofood Research and Innovation Centre, \\ 400650 Cluj-Napoca, Romania \\ 4 Centre for Innovative Process Engineering (CENTIV) GmbH, 28857 Syke, Germany \\ 5 Food Hygiene and Quality Control, University of Zabol, Zabol 98615-538, Iran; zagrosman1989@gmail.com \\ * Correspondence: rusu_alexandru@hotmail.com (A.R.); monica_trif@hotmail.com (M.T.); \\ wyy10421@163.com (Y.W.) \\ + These authors contributed equally to this work.
}

Citation: Farooq, M.; Azadfar, E.; Rusu, A.; Trif, M.; Poushi, M.K.; Wang, Y. Improving the Shelf Life of Peeled Fresh Almond Kernels by Edible Coating with Mastic Gum. Coatings 2021, 11, 618. https:// doi.org/10.3390/coatings11060618

Academic Editor: Louis Kuoping Chao

Received: 15 April 2021

Accepted: 17 May 2021

Published: 21 May 2021

Publisher's Note: MDPI stays neutral with regard to jurisdictional claims in published maps and institutional affiliations.

Copyright: (c) 2021 by the authors. Licensee MDPI, Basel, Switzerland. This article is an open access article distributed under the terms and conditions of the Creative Commons Attribution (CC BY) license (https:/ / creativecommons.org/licenses/by/ $4.0 /)$.

\begin{abstract}
Coating, as a process in which fruits, vegetables, kernels, and nuts are covered with an edible layer, is an environmentally friendly alternative to plastic wrapping, which has been considered the most effective way to preserve them over the long term. On the other hand, prolonging the shelf life results in a reduction of spoilage and therefore achieving a goal that is very important nowadaysthe reduction of food waste. The quality of preserved almonds kernels depends on factors such as grain moisture, storage temperature, relative humidity, oxygen level, packaging, and the shape of the stored nuts (along with being peeled, unpeeled, roasted, etc.). The commercial importance of the almond fruit is related to its kernel. Almonds that are peeled (without the thin brown skin) and stored have a shorter shelf life than unpeeled almonds since the reddish-brown skin, rich in antioxidants, may protect the kernels against oxidation. In this study, a bioactive edible coating has been tested, which may provide an effective barrier against oxygen permeation and moisture, thus preserving the quality of peeled fresh almonds by extending their shelf life. Mastic gum, as a natural coating agent, was used to coat the peeled fresh almond kernels in four different concentrations $(0.5 \%$, $1.0 \%, 1.5 \%$, and $2.0 \% \mathrm{w} / \mathrm{v}$ ). The effect of mastic gum coating on the quality parameters of the peeled fresh almonds (moisture uptake, oil oxidation, total yeast and mold growth, and Aspergillus species development) was studied during four months of storage. The results showed that mastic gum, as a coating agent, significantly $(p<0.05)$ reduced moisture absorption, peroxide and thiobarbituric acid indices, total yeast and mold growth, and Aspergillus species development in the peeled and coated fresh almonds, compared to the control, i.e., uncoated fresh almonds, during 4 months of storage, packed at room temperature $\left(25-27^{\circ} \mathrm{C}\right)$ inside a cabinet at $90 \%$ humidity. Therefore, mastic gum can be used as a great natural preservative coating candidate with antioxidant and antimicrobial effects.
\end{abstract}

Keywords: almond; mastic gum; natural edible coating; preservation; shelf life

\section{Introduction}

Currently, researchers are testing innovative protective layers that are supposed to keep the fruit, vegetables, and kernels fresher longer. The layers, also called edible coating, are colorless, odorless, tasteless, and harmless to health, and they can even be consumed without hesitation since they consist of natural or microbiological sources. The edible coating can reduce packaging waste, food waste, and greenhouse gases. It is sprayed or spread on fruit, vegetables, and kernels and creates a barrier that controls how much water 
and carbon dioxide leak from the fruit, vegetables, and kernels, and how much oxygen enters from the outside [1-3].

Many foods processing have still a long way to go in terms of food safety, and almonds are no exception. Europe asa continent is far away from becoming a major region of food production. Almost every day, manufacturers recall foods because they contain contaminants. Even dry goods, which are considered safe due to their lack of water, are also regularly withdrawn from the market. This is because harmful microorganisms can settle on these foods during processing. According to the consumer protection center in Germany, as an example, the number of food recalls with almonds rapidly grew between 2015 and 2019. If the affected products endanger health, the manufacturer must take them off the market and inform the consumer $[4,5]$.

Almond, with the scientific name of Prunus amygdalus, is one of the dark rose plants belonging to dicotyledons. Almond is a tree native to West Asia, the southern shore of the Mediterranean Sea, and one of the oldest dried fruit trees. The plant grows well in hot and dry climates; the main area of almond production in the world is the central plains of California, and the second-largest area of almond production includes European countries along the Mediterranean. The United States leads the global almond production with an approximate $80 \%$ share, followed by Asia, and Tunisia. Iran is one of the producers of almonds in Asia, due to its favorable climatic conditions for growing almonds. Almond kernels represent the commercial importance of almond fruit [6].

Almonds are used by many manufacturers around the world for a wide variety of products. Due to the desirable sensory properties, almond kernels are used as an ingredient in the preparation of many food products such as beverages, ice cream, chocolate, sweets, and breakfast cereals [6-9].

To ensure the best possible quality, various steps are necessary in order to select the right processing and storage methods. Research has been carried out extensively to understand the effect of moisture on the quality and shelf life of almonds. This paves the way for developing tools and resources to maximize almonds' quality, from cultivation to storage and distribution [9-11]. Increased temperatures and humidity can lead to a significant loss of quality and reduced almond shelf life, besides accelerating the concealed damage. The concealed damage, a light-to-dark-brown discoloration in the almond kernel's interior, is called a "hidden defect," which is specific to almond kernels, resulting in a very bitter off-taste. Therefore, almonds should ideally be protected during storage [12,13].

Almond kernels are appreciated as high-calorie and rich foods. The core of fresh almonds (400-600 kcal/100 g) is rich in fat, total lipids (35-66\% f.w. (fresh weight)), total protein (considering a conversion $\mathrm{N}$ factor of $5.18 ; 14-61 \%$ f.w.), fiber (11-14\% f.w.), vitamins (E (antioxidant), B2, B9, B3, and B1), macronutrients (P, K, Ca, and Mg), micronutrients $(\mathrm{Fe}, \mathrm{Cu}, \mathrm{Mn}$, and $\mathrm{Zn}$ ), and carbohydrates (4-28\% f.w.), of which soluble sugars comprise $2.5-12 \%$. At the same time, they provide health-promoting bioactive phytochemical compounds (phytosterols, tocopherols, squalene, stanols, sphingolipids, phospholipids, chlorophylls, carotenoids, phenols, and volatile compounds). The proportion of these compounds changes according to the cultivars, the cultivation system, and the geographical origin [6,14-19].

Almonds contain $55-70 \%$ oil, with beneficial health effects but very sensitive to oxidation [20-22]. The almond oil is rich in monounsaturated fatty acids (MUFA, 60\%) and polyunsaturated fatty acids (PUFA, 30\%) [23-26].

Even by-products derived from the grinding of the pressing cake of almond oil extraction are of importance because they generate partially defatted flour. These flours have been reported to have promising uses in the culinary industry to enhance the nutritional properties of various products; such products aim to replace traditional meat-based products [27].

The oxidative process leads to unpleasant odors and tastes in almonds, and concealed damage. All these shorten their shelf life at ambient conditions and during storage; therefore, the resulting products lack the necessary quality for human nutrition $[28,29]$. 
Moreover, almonds that are peeled (skinless, without the thin brown skin) and stored have a shorter shelf life than unpeeled almonds since the reddish-brown skin, rich in antioxidants, may have a protective role against oxidation, but many food recipes call for skinless almonds $[25,30]$. Packaging and storing conditions are very important factors to prevent oxidation and maintain optimum flavor, avoiding, at the same time, concealed damage.

In order to extend the shelf life of nuts, including almonds, and retard lipid oxidation, research has been carried out extensively to study the use of bio-based edible coatings. The edible coating may provide an effective barrier against oxygen permeation and moisture, thus preserving the quality of nuts by extending their shelf life [31-34].

Due to the increasing demand for sources of bioactive biodegradable/edible films and coatings, there is a need to explore the novel and underutilized sources of raw materials with functional properties for preservation and shelf-life extension of foods [35]. Therefore, natural tree resins, excreted by trees or bushes when injured, and natural tree gums, may be promising alternatives for coating, as substitutes for materials from nonrenewable sources [36].

Mastic gum, a plant resin, is obtained from a special type of pistachio, a variety of Pistacia lentiscus (family: Anacardiaceae). The viscous resin emerges in tear shaped droplets from the bark of the mastic bush and therefore also called "tears".

Several studies on the biological properties of mastic gum have shown positive therapeutic effects in anticancer activity, improving the immune system, cardiovascular disease, inhibiting free radicals, inhibiting lipid peroxidation, and stimulating the activity of antioxidant enzymes. Ancient doctors recommended this sap to treat periodontal disease or pimples. The sap was also used for digestive problems, such as stomach pain, heartburn, and stomach ulcers, as well as for wound treatment or rheumatic complaints. It has been shown that mastic acts throughout the gastrointestinal system or that it lowers cholesterol, blood sugar, and blood pressure. New studies confirm its antibacterial effectiveness: germs that are responsible for the formation of caries and periodontitis can be successfully reduced with mastic. There are also studies on the effects on oral hygiene, for example, in the case of tooth decay, xerostomia (dry mouth or oral dryness), or gingivitis, and on the skin [37-41].

Due to the numerous positively proven bioactive properties, mastic gum received increasing attention, and the demand for it has increased in recent years. Moreover, in different areas such as food supplements, general cosmetic products, toothpaste or mouthwash products, industrial uses, animal nutrition, and for natural flavors in food, confectionery, and beverages, there is a need for bio-based materials, such as natural materials, as substitutes for materials from nonrenewable sources replacing traditional petroleum polymers in several industrial sectors, which provide additional properties, such as antimicrobial, antioxidant, anti-inflammatory effects. Almond kernels during storage are highly exposed to fungi contamination, resulting in the production of toxins (metabolites produced by Aspergillus species) and increased mold and yeast counts. However, most of the cases, contaminated almonds leave no visually visible wounds or discoloration, posing a risk to public health can lead in the seemingly defect-free final product [42].

A low temperature (around $4{ }^{\circ} \mathrm{C}$ ), as an ideal storage parameter, seems to reduce aflatoxin levels and mold and yeast count for 3-6 months [43].

The aim of this study was to investigate the effect of bioactive edible coating of mastic gum on fresh almond kernels (variety Carmel cultivar from Artin Azma, Lorestan Province, Iran), and to evaluate the quality parameters (moisture uptake, oil oxidation, total yeast, and mold growth, and Aspergillus species development) during 4 months of the storage period, packed at room temperature $\left(25-27^{\circ} \mathrm{C}\right)$ inside a cabinet and at $90 \%$ humidity.

\section{Materials and Methods}

\subsection{Materials}

To conduct the present research, mastic gum (Pistacia lentiscus) was purchased from the medicinal plants' store city (Artin Azma, Lorestan Province, Iran), and the fresh almond 
from cultivar Carmel was purchased from Lorestan Province, Iran. All chemicals needed and plate count agar (PCA) medium were purchased from Merck (Hamburg, Germany).

\subsection{Methods}

\subsubsection{Edible Coating Preparation}

In order to prepare mastic gum solutions with concentrations of $0.5 \%, 1 \%, 1.5 \%$, and $2 \%(w / v)$, respectively, $5,10,15$, and $20 \mathrm{~g}$ of mastic gum powder were added to one liter of distilled water, slowly and in several steps. The solution was then stirred with a glass stirrer. The solution was filtered afterward with Whatman grade 3 qualitative filter paper $\varnothing 185 \mathrm{~mm}$.

\subsubsection{Covering, Packing, and Storage Study of Fresh Almond Kernels}

First, after raw almonds were dehulled (separating the green skins), the whole fresh almond seeds were dried using a cabinet dryer (Artin Azma, Yavari st, Madani Ave, Resalat.Ave Tehran, Iran) at $43{ }^{\circ} \mathrm{C}$ until a moisture content of $5 \%$ (AOAC, 2005) was achieved [44]. Then, the almonds were crushed manually, to remove the shell, and peeled (skinless, without the thin brown skin), and healthy kernels were selected. The hull, shell, and skin are considered almond by-products [45]. The peeled fresh almond kernels were then weighed and placed in lattice containers.

Afterward, they were immersed in containers with the corresponding coating solution for $30 \mathrm{~s}$ and removed. After coating, to remove excess moisture, the almonds were left for the excess solution to drop off, and to dry off the excess moisture, they were dried in an oven at $40{ }^{\circ} \mathrm{C}$ for $4 \mathrm{~h}$ until they reached an average humidity of $2.5 \%$ [46,47].

Five treatments were prepared using fresh almonds skinless: uncoated fresh almonds (control sample), and coated fresh almonds with mastic gum in different concentrations, $0.5 \%, 1 \%, 1.5 \%$, and $2 \%(w / v)$, respectively.

Almonds were completely randomly divided into $50 \mathrm{~g}$ units using a digital scale (A\&D Co, LTD, Lorestan, Japan) with an accuracy of 0/001 and packed in commercial plastic bags with dimensions of $6 \mathrm{~cm} \times 20 \mathrm{~cm}$. Packed almonds were stored for 4 months at room temperature $\left(25-27^{\circ} \mathrm{C}\right)$ inside a cabinet and at $90 \%$ humidity.

The percentage of moisture was calculated according to the following equation:

$$
\% \text { moisture }=\left(m_{\mathrm{W}} / m_{\text {sample }}\right) \times 100,
$$

where,

$m_{\mathrm{w}}=$ mass of the water;

$m_{\text {sample }}=$ mass of the sample.

\subsubsection{Chemical Analysis}

Chemical Decomposition of Almond Kernels

Measurements of moisture, ash, fat, fiber, protein, and carbohydrates of fresh almond kernels were performed using AOAC (2007) standard methods at 926-12, 923-03, 992-23, and 948-22, respectively [43]. The percentage of carbohydrates was determined according to AOAC (2007) [48]. The percentage of fiber was calculated according to the AACC standard (2000) number 1-33 (AACC, 2000) [49]. Total moisture, ash, fat, fiber, protein, and carbohydrates were subtracted from $100 \mathrm{~g}$ fresh almonds.

Assessment of Oxidation

Measurement of Peroxide Index (PI)

Almond kernel oil was extracted under room temperature $\left(25-27^{\circ} \mathrm{C}\right)$ condition in a dark place using normal hexane solvent [50], and peroxide index, as an indicator of primary oxidation product, was measured by an iodometric method in accordance with the standard of the American Oil Chemists' Society (AOCS, 2003) [51].

Measurement of Thiobarbituric Acid Index (TBA) 
Thiobarbituric acid index, as an indicator of secondary oxidative aldehyde products, was measured according to the American Oil Chemists' Society (AOCS, 2004) [51-53].

\subsubsection{Total Yeast and Mold Counts (TYMC)}

To perform the total yeast and mold counts, $10 \mathrm{~g}$ of each uncoated and coated almonds were pounded with a sterile mortar under the flame and the microbial hood (Karen Pouya Noavar, Tehran, North Kargar St Boulevard Saman, Tower Iran). Almonds powder, along with $90 \mathrm{~mL}$ of $0.9 \%$ sterilized sodium chloride solution, was transferred to a stomacher bag and mixed thoroughly in the stomacher device (Stomacher Bag Mixer 400 SW Interscience, Artin Azma, Iran). Dilutions $10^{-2}$ and $10^{-3}$ were obtained from dilutions of $10^{-1}$. A total of $0.1 \mathrm{~mL}$ of each dilution was added to the PCA solid culture medium using a sampler and completely spread on the culture medium using a special glass rod (Arian Company, Artin Azma, Iran).

After a few minutes, the plates were heated upside down at 20 to $25^{\circ} \mathrm{C}$. After 5 days, the number of grown mold and yeast were counted and reported in cfu/gr unit.

\subsubsection{Antifungal Characteristic of Mastic Gum against the Growth of Aspergillus Species}

For this purpose, $10 \mathrm{~g}$ of almond kernels from each of the coated and uncoated samples were placed in large glass plates containing wet filter paper and all of which were sterilized and then incubated at $25^{\circ} \mathrm{C}$. After 5 days, the number of plates infected with fungi was counted, and the rate of fungi development was determined based on the percentage in each sample (coated almond kernels), compared to the control sample (uncoated almond kernels).

If necessary, the fungi grown on almond kernels were cultured on a culture slide, and the growth of Aspergillus species was ensured under an electronic microscope.

All measurements were measured at intervals of 1 month to 4 months in three replications.

\subsection{Statistical Analysis}

The experiments were performed in three replications in a completely randomized design, and the obtained data were statistically analyzed. After analysis of variance, the means were compared using Duncan's multiple range test at the level of 0.05 by SAS (Statistical Analysis System) software (version 9.2). Word Excel 2013 software was used to draw the graphs.

\section{Results}

\subsection{Fresh Skinless Almond Kernels' Nutritional Chemical Composition}

The nutritional composition of fresh almond kernels used in the current study, before the coating, is shown in Table 1. Almond kernels composition is of great interest from the nutritional points of view and therefore very important for commercial and industrial applications. It seems that the almond kernels used in this study present compounds in concentrations reported already with high nutritional value [14-19].

Table 1. Nutritional content of uncoated fresh almond kernels.

\begin{tabular}{cccccc}
\hline Moisture (\%) & Protein (\%) & Fat (\%) & Ash (\%) & Fiber (\%) & Carbohydrate (\%) \\
\hline $5.13 \pm 0.25$ & $16.13 \pm 0.65$ & $62.01 \pm 0.06$ & $3.13 \pm 0.11$ & $4.06 \pm 0.14$ & $13.6 \pm 0.11$ \\
\hline
\end{tabular}

According to Table 1, the fresh almond kernels are very fatty, with- $62.0 \% \pm 01.06 \%$ of fat, and if their storage conditions are unsuitable, this aspect makes them susceptible to lipid oxidation, rancidity development, and concealed damage. This may influence shelf life, resulting in a very bitter off-flavor and a low acceptance rate among consumers [9-11,22-30]. 


\subsection{The Effect of Coating with Mastic Gum}

\subsubsection{On Moisture Content}

Humidity is one of the important factors in maintaining the quality of kernels. The rate of moisture transfer between food and the surrounding atmosphere is reduced by completely covering the food with film or by coating [54].

Figure 1 shows the changes in the moisture content (\%) of fresh almond kernels uncoated and coated with different mastic gum concentrations over a 4-month storage period conditions. As can be observed, although the average amount of moisture absorption in all samples during the storage period is associated with an increasing trend, the coating with mastic gum significantly reduced moisture absorption, compared to uncoated samples, during the storage period.

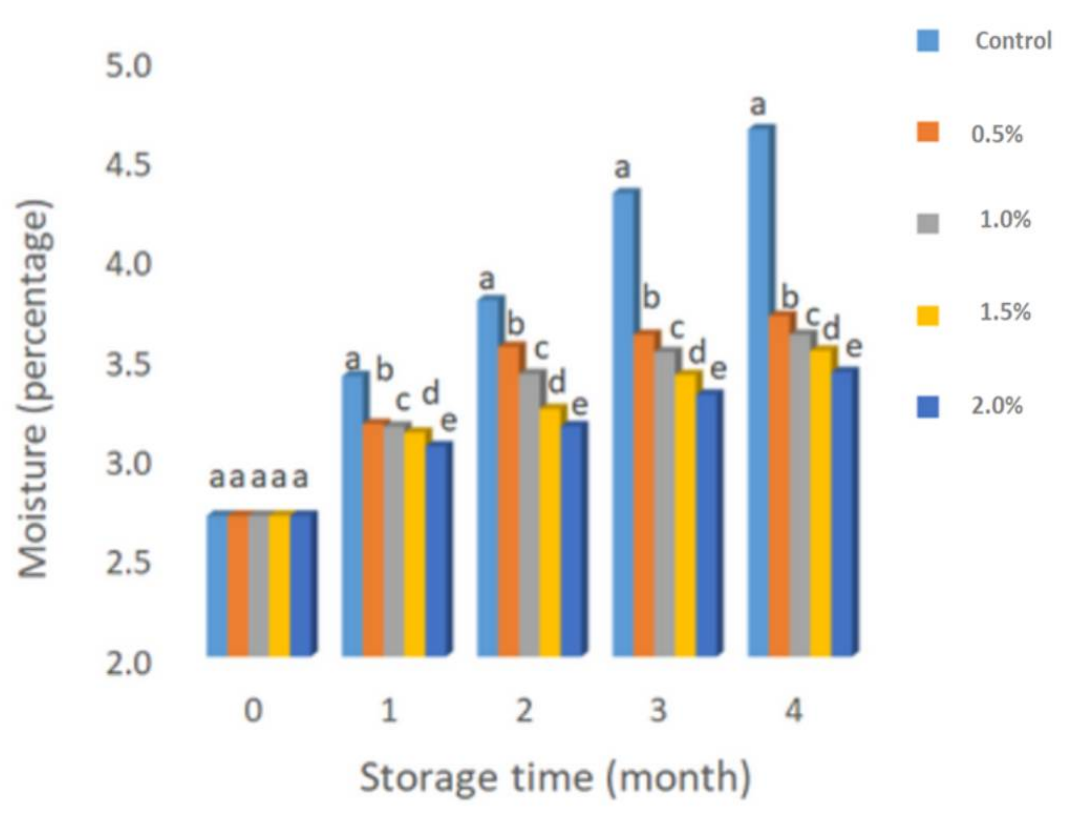

Figure 1. Changes in the moisture content (\%) of uncoated (control) and coated almond kernels during 4 months of storage. Different lowercase letters indicate a statistically significant differences $(p<0.05)$ between the samples during each month; share a lowercase letter are not statistically different, while different letters denote for statistical differences at least $95 \%$ confidence.

\subsubsection{On Peroxide Index}

Peroxide index (PI) is the most common sign of oxidative spoilage in kernels [55]. Oxidation of lipids in food is one of the most important factors in food degradation during processing, storage, and distribution and leads to adverse effects on aroma, color, nutritional value, and the production of toxic compounds [56].

The presence of unsaturated fatty acids makes almond oil susceptible to oxidation, as previously mentioned. The effect of coating with mastic gum in different concentrations on the trend of changes in almond kernel peroxide index during four months of storage period and conditions, based on mill equivalents of oxygen per $\mathrm{kg}$ of almond oil, is presented in Table 2. The results show that the trend of changes in the peroxide index of all samples increased significantly during the storage period. The PI of fresh almond kernel uncoated (control) was 0.24 mill equivalents of oxygen per kilogram, and after 4 months under storage conditions, PI reached 1.12 mill equivalents of oxygen per kilogram of oil. 
Table 2. Changes in the peroxide value of uncoated (control) and coated almonds during 4 months of storage in mill equivalents of oxygen per kilogram of oil.

\begin{tabular}{cccccc}
\hline & \multicolumn{3}{c}{ Time (Months) } \\
\hline Sample & $\mathbf{0}$ & $\mathbf{1}$ & $\mathbf{2}$ & $\mathbf{3}$ & $\mathbf{4}$ \\
\hline Control & $0.24 \pm 0.001 \mathrm{Ea}$ & $0.41 \pm 0.001 \mathrm{Da}$ & $0.57 \pm 0.003 \mathrm{Ca}$ & $0.88 \pm 0.002 \mathrm{Ba}$ & $1.12 \pm 0.011 \mathrm{Aa}$ \\
\hline $\begin{array}{c}\text { Coating with } \\
0.5 \%(w / v)\end{array}$ & $0.24 \pm 0.001 \mathrm{Ea}$ & $0.36 \pm 0.002 \mathrm{Dab}$ & $0.48 \pm 0.002 \mathrm{Cb}$ & $0.78 \pm 0.001 \mathrm{Bb}$ & $1.07 \pm 0.001 \mathrm{Ab}$ \\
\hline $\begin{array}{c}\text { Coating with } \\
1 \%(w / v)\end{array}$ & $0.24 \pm 0.001 \mathrm{Ea}$ & $0.33 \pm 0.001 \mathrm{Db}$ & $0.41 \pm 0.001 \mathrm{Cc}$ & $0.66 \pm 0.002 \mathrm{Bc}$ & $0.96 \pm 0.002 \mathrm{Ac}$ \\
\hline $\begin{array}{c}\text { Coating with } \\
1.5 \%(w / v)\end{array}$ & $0.24 \pm 0.001 \mathrm{Ea}$ & $0.27 \pm 0.001 \mathrm{Dc}$ & $0.37 \pm 0.001 \mathrm{Cd}$ & $0.56 \pm 0.01 \mathrm{Bd}$ & $0.86 \pm 0.013 \mathrm{Ad}$ \\
\hline $\begin{array}{c}\text { Coating with } \\
2 \%(w / v)\end{array}$ & $0.24 \pm 0.001 \mathrm{Da}$ & $0.27 \pm 0.002 \mathrm{Dc}$ & $0.35 \pm 0.001 \mathrm{Cd}$ & $0.53 \pm 0.001 \mathrm{Bd}$ & $0.82 \pm 0.011 \mathrm{Ad}$ \\
\hline
\end{tabular}

Different capital letters in each row indicate a statistically significant difference in each sample during different months at the level of 5\%; Different lowercase letters in each column indicate a statistically significant difference between the samples during each month at the level of $5 \%$.

The highest and lowest PI values, after 4 months of storage, were related to the control sample (uncoated almonds) and the sample of almonds coated with $2 \%(w / v)$ mastic gum, respectively. The PI values of the almond samples coated with $1.5 \%$ and $2 \%(w / v)$ of mastic gum were not significantly different, as can be seen; concluding that coating with $1.5 \%$ mastic gum offers good almonds protection as well.

\subsubsection{On Thiobarbituric Acid Index (TBA)}

Measurement of TBA index is a method for detecting by-products of fat oxidation in fatty food products [57]. By-products change the taste of the product, cause food spoilage, and have adverse effects on the nutritional value of the product, which makes it difficult to use kernels in other products [58]. The changes in the value of the TBA index in the tested uncoated and coated almonds samples are shown in Table 3.

Table 3. Changes in the peroxide value of uncoated (control) and coated almonds during 4 months storage in mill equivalents of oxygen per kilogram of oil.

\begin{tabular}{cccccc}
\hline \multicolumn{5}{c}{ Time (Months) } \\
\hline Sample & $\mathbf{0}$ & $\mathbf{1}$ & $\mathbf{2}$ & $\mathbf{3}$ & $\mathbf{4}$ \\
\hline Control & $0.014 \pm 0.0001 \mathrm{Ea}$ & $0.023 \pm 0.0011 \mathrm{Da}$ & $0.039 \pm 0.0002 \mathrm{Ca}$ & $0.048 \pm 0.0003 \mathrm{Ba}$ & $0.059 \pm 0.0011 \mathrm{Aa}$ \\
\hline $\begin{array}{c}\text { Coating with } \\
0.5 \%(w / v)\end{array}$ & $0.014 \pm 0.0011 \mathrm{Ea}$ & $0.021 \pm 0.0013 \mathrm{Db}$ & $0.035 \pm 0.0003 \mathrm{Cb}$ & $0.042 \pm 0.0006 \mathrm{Bb}$ & $0.053 \pm 0.0011 \mathrm{Ab}$ \\
\hline $\begin{array}{c}\text { Coating with } \\
1 \%(w / v)\end{array}$ & $0.014 \pm 0.0001 \mathrm{Ea}$ & $0.021 \pm 0.0016 \mathrm{Db}$ & $0.032 \pm 0.0002 \mathrm{Cc}$ & $0.039 \pm 0.0011 \mathrm{Bc}$ & $0.045 \pm 0.0003 \mathrm{Ac}$ \\
\hline $\begin{array}{c}\text { Coating with } \\
1.5 \%(w / v)\end{array}$ & $0.014 \pm 0.0002 \mathrm{Ea}$ & $0.019 \pm 0.0012 \mathrm{Dbc}$ & $0.030 \pm 0.0011 \mathrm{Ccd}$ & $0.034 \pm 0.0011 \mathrm{Bd}$ & $0.042 \pm 0.0002 \mathrm{Ad}$ \\
\hline $\begin{array}{c}\text { Coating with } \\
2 \%(w / v)\end{array}$ & $0.014 \pm 0.0011 \mathrm{Ca}$ & $0.018 \pm 0.0002 \mathrm{Bc}$ & $0.028 \pm 0.0001 \mathrm{ABd}$ & $0.033 \pm 0.0012 \mathrm{ABd}$ & $0.040 \pm 0.0003 \mathrm{Ad}$ \\
\hline
\end{tabular}

Different capital letters in each row indicate a statistically significant difference in each sample during different months at the level of $5 \%$; Different lowercase letters in each column indicate a statistically significant difference between the samples during each month at the level of $5 \%$.

As can be observed in Table 3, the TBA index increased significantly during the storage period in uncoated almonds samples, compared to almonds coated with $1 \%, 1.5 \%$, and $2 \%$ $(w / v)$ mastic gum. There is no significant difference between control and coating with $0.5 \%$ mastic gum, thus providing slight protection. 


\subsubsection{Microbiological Analysis Results}

Total Yeast and Mold Counts (TYMC)

The results of the TYMC in almond kernels uncoated (control) and coated with different concentrations of mastic gum during the 4-month storage period are shown in Figure 2. According to the results obtained during the storage period, the growth rate of mold and yeast in the control sample increased significantly, while coated almonds with mastic gum significantly reduced the overall mold and yeast, compared to the control sample, at each stage of sampling during the storage period. In the middle of the storage period (day 105), differences in the mean values among treatments began to appear.

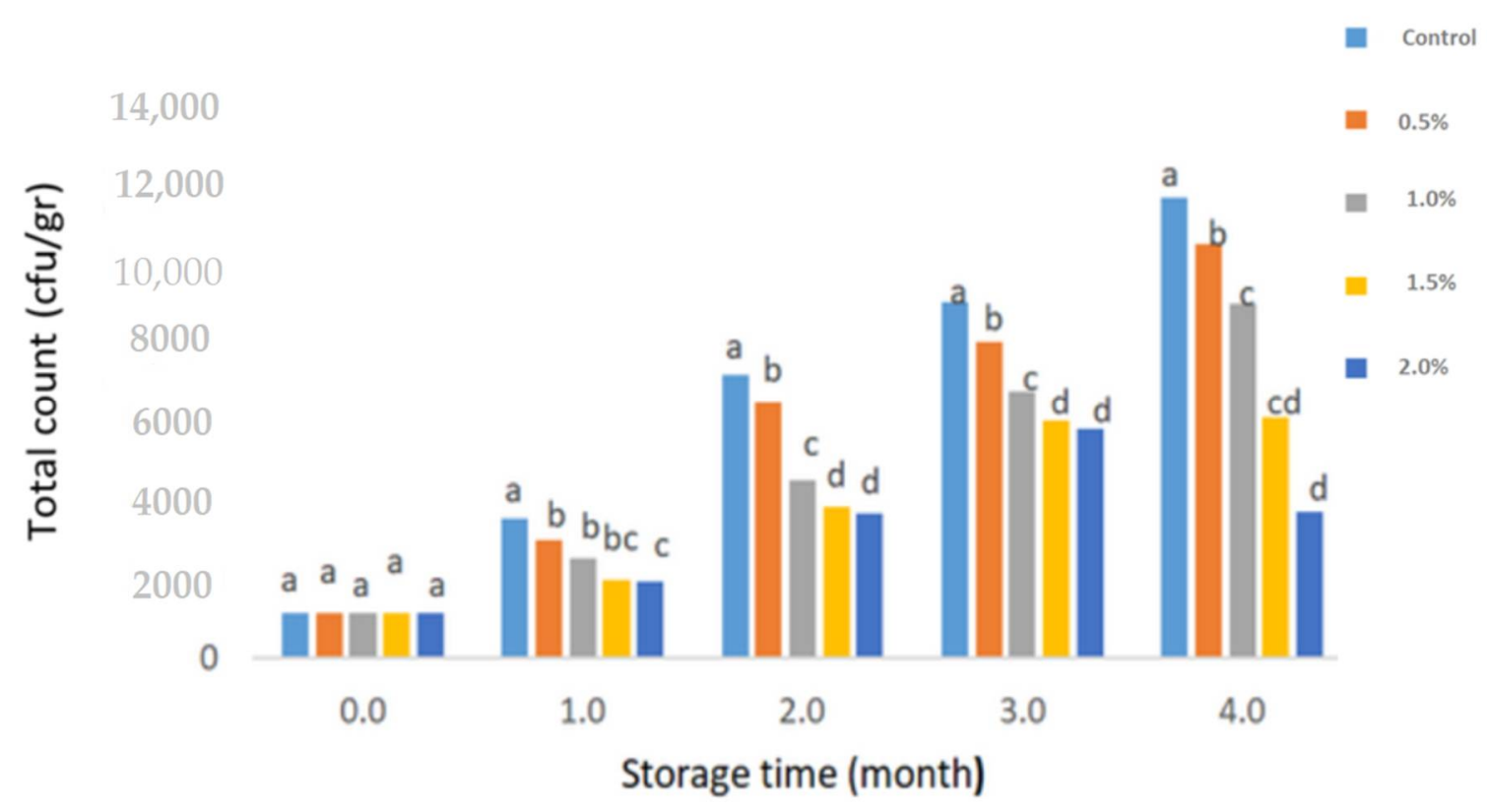

Figure 2. Changes in TYMC load of uncoated (control) and coated almonds with mastic gum in different concentrations during 4 months storage. Different lowercase letters indicate a statistically significant differences $(p<0.05)$ between the samples during each month; share a lowercase letter are not statistically different, while different letters denote for statistical differences at least $95 \%$ confidence.

The total number of mold and yeast increased from 1150 to $11,700 \mathrm{cfu} / \mathrm{gr}$ after 4 months of storage in the control sample, while the total number of mold and yeast in the samples coated with $2 \%(w / v)$ mastic gum decreased from 11,700 to $3700 \mathrm{cfu} / \mathrm{gr}$, compared to the uncoated sample.

Antifungal Characteristic of Mastic Gum Coating against the Growth of Aspergillus Species

Aflatoxins may occur in contaminated almonds, and, in general, in contaminated foods, with fungi from Aspergillus species as carcinogenic secondary metabolites. Factors such as environmental conditions (e.g., temperature, relative humidity) affect mold growth and aflatoxin production [59].

The contamination with Aspergillus spp. of almonds, as in other nuts (such as peanut, hazelnut, walnut), occurs generally during harvest, processing, and storage. It is very important to prevent the postharvest mold contamination and growth of the susceptible almonds, and nuts [1,42].

The results of the present study regarding Aspergillus spp. mold development on fresh almond kernels uncoated and coated with different mastic gum concentrations during the 4 months of storage period are shown in Figure 3. As can be seen in the figure, mastic gum coating significantly reduced the growth rate of Aspergillus spp. Mold, compared to control samples. 


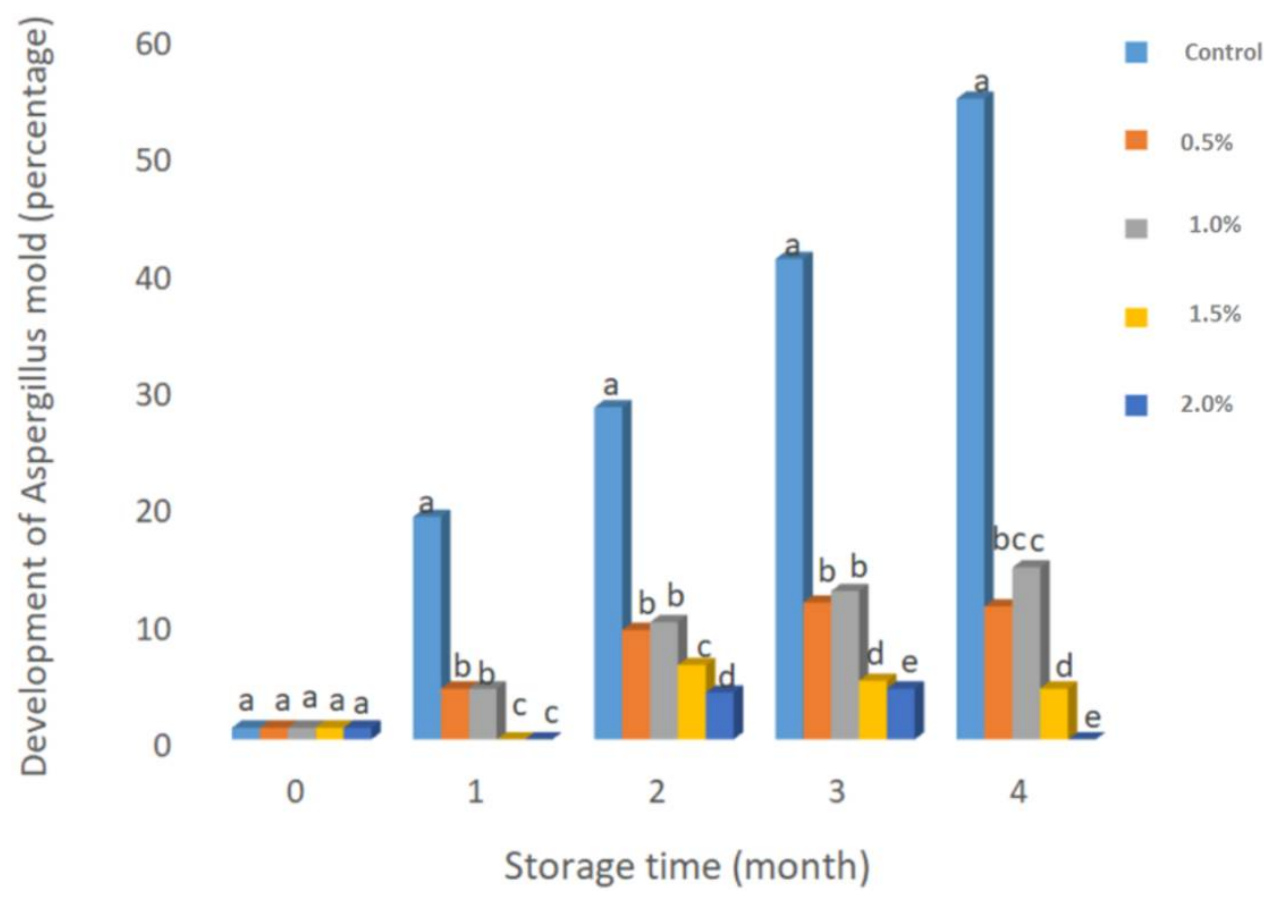

Figure 3. Percentage of the growth of Aspergillus species on almond uncoated (control) and coated with different concentrations of mastic gum during 4 months of storage. Different lowercase letters indicate a statistically significant differences $(p<0.05)$ between the samples during each month; share a lowercase letter are not statistically different, while different letters denote for statistical differences at least $95 \%$ confidence.

The contamination with aflatoxins produced by Aspergillus spp. represents a major public health concern and, in addition to the possible contamination with other kinds of mold and yeast, causes food spoilage. Investigations on minimizing or eliminating such contaminants are an ongoing research topic, and the results of the present study contribute with new results to this area of research.

\section{Discussion}

Plant-based foods that are consumed raw are susceptible to changes in quality during processing. They can be contaminated with germs and thus represent a source of food infections. Dry foods such as almonds, nuts, dried fruits, spices, milk powder, or dried teas are not excluded. Almond kernels are very fatty, rich in oleic (main monounsaturated fatty acids) and linoleic acids (polyunsaturated fatty acids). The ratio of these two fatty acids is at a higher level than in the various common nut oils, vegetable oils (e.g., soybean), and seed (e.g., pomegranate, grape, date, and sesame) oils [28,60].

Moreover, the high content of these fatty acids in almonds, contributing to shorter shelf life, compared to other nuts, in addition to the presence of riboflavin as a photosensitizer in almonds, makes almonds susceptible to auto-oxidation, which is the main cause of off-flavor development in almonds, both in wild or domestic species of almonds. Environmental factors (e.g., storage temperature, packaging techniques, moisture, and light) play an active role in influencing lipid oxidation [28,61].

Several suitable packaging materials and techniques (e.g., modified atmosphere packaging or vacuum packaging) and storage temperatures have been tested and proposed to extend the shelf-life period of various types of nuts and almond kernel products [28,62-66]. Major challenges during storage and limitations for usage, for example, as snack mix nuts and almond products, may be considered.

The quality of almonds and other nuts can be affected by moisture, another important factor to be taken into consideration. When moisture is too high, it influences the deterio- 
rative reactions, and therefore, mold growth occurs. However, too low levels of moisture have another kind of influence on the kernel shrivel [67].

Recently the application of edible coating based on bio-based antimicrobial and bioactive materials, such as natural plant materials or from different renewable resources, as substitutes for materials from nonrenewable sources, has received attention, contributing to extending the shelf life of natural perishable products while developing healthy and natural foods. The use of edible films (e.g., polysaccharides and proteins) for extending the shelf life of different nuts, including almonds, has been studied, and research is still ongoing [1,31-34,52,68-70].

The main objective of the present study was to enhance the durability of stored fresh almond kernels without becoming spoiled by pathogens and affected by moisture, which are the routes that cause food spoilage. Almond kernels, as the main commercial importance of almond fruit, are widely used in different food products; lately, snack mix nuts and almonds are the top products preferred. Even athletes appreciate almond kernels for their plant-based proteins and their essential amino acids. Moreover, recent studies have explored the effect of other nutritional compounds of almonds such as fiber on gut microbiota or the antioxidant capacity of the protein fraction [71-75].

In the present study, mastic gum was analyzed to be used as an alternative for fresh almonds coating for preservation, against contamination with molds, yeast, and fungi during storage over 4 months. Many countries determined the toxin limits for some foods such as pistachio, almonds, peanut, walnut, and hazelnut. Additionally, most importantly is that EU imports of different Iranian nuts decreased due to the increasing contamination risk incidents originated from Iran [76,77]. If contaminated almonds enter the production facilities after harvest, they can also contaminate other batches.

Evaluation of the sample's moisture content during the storage period showed a statistically significant difference $(p<0.05)$ between the samples with mastic gum coating and the control sample. By increasing the concentration of mastic gum, the moisture content of almond kernels during the storage period was decreased.

These results indicate that the mastic gum coating, as a barrier, reduces the transfer of moisture to the almond kernel tissue and increases its inhibitory effect by increasing the thickness of the coating. Similar results were achieved on the effect of coating almonds or other nuts kernels with different kinds of edible coating materials, and with increasing the thickness of the coating, its inhibitory effect increases [68-70,78-81].

Moreover, the oxidation potential is increased, and the fats have a longer shelf life, i.e., the almonds do not go rancid as quickly [82].

It can be stated that the surface coating of the product reduces the passage of water molecules and improves the durability of the product. It is believed that the bioactive phytochemical compounds (phytosterols, tocopherols, squalene, stanols, sphingolipids, phospholipids, chlorophylls, carotenoids, phenols, and volatile compounds) are present as active antioxidant compounds in the composition of mastic gum [14-19]. The decrease in peroxide and thiobarbituric acid index can be attributed to the presence of triterpenics. The simultaneous presence of antioxidant compounds may create a boosting state and increase total antioxidant activity.

On the other hand, studies have confirmed its efficacy as a functional food for gastrointestinal disturbances or several modern lifestyle-related diseases of consumers who have been using mastic daily for many years in the form of chewing gum for oral health, or in powder or capsule [83-85].

Therefore, using mastic gum as a coating material could have double benefits, extending the shelf-life of a food product and, at the same time, promoting health benefits associated with its compounds. This could lead to a decrease in their nutritional content because the products with a protective layer can be stored longer. 


\section{Conclusions}

The results of the present study indicated that mastic gum coating used in four different concentrations $(0.5 \%, 1 \%, 1.5 \%$, and $2 \% w / v)$ containing different bioactive compounds was effective significantly $(p<0.05)$ against moisture absorption and oxidative reactions, total yeast and mold growth, and Aspergillus species development in peeled and coated fresh almonds, compared to uncoated fresh almonds as the control sample, during 4 months of storage, packed at room temperature $\left(25-27^{\circ} \mathrm{C}\right)$ inside a cabinet at $90 \%$ humidity. By increasing the concentration of mastic gum, the protection against environmental factors during the storage period increased.

It could be concluded that mastic gum coatings could be effectively utilized to extend the shelf life of peeled fresh almonds and other nuts (containing high fatty acids content), on the one hand, and promoting health benefits, on the other hand, due to its valuable bioactive components. To our knowledge, there is no information in the literature on the use of mastic gum neither as edible coating nor on coating fresh almonds using mastic gum as edible coating to maintain the quality of the product during storage.

Due to the increase in the oxidation potential of fats, it is of potential interest for those with increased sensitivity to oxidation.

In addition, existing products in the market with coatings are around twice as expensive as those without, and so far, the consumer has paid for these additional costs, not the supermarket. Therefore, an edible coating such as natural mastic gum will open new perspectives.

Mastic gum belongs to the next generation of bio-based materials, such as natural plant materials, as substitutes for materials from nonrenewable sources, replacing traditional petroleum polymers in several industrial sectors.

Author Contributions: Conceptualization, M.F. and Y.W.; methodology, M.F., E.A., and M.K.P.; investigation, M.F., M.K.P., and Y.W.; data curation, M.F., E.A., and M.K.P.; writing—original draft preparation, M.F. and Y.W.; writing—review and editing, A.R. and M.T.; visualization, A.R. and M.T.; supervision, M.F. and Y.W.; publication funding, A.R. and M.T. All authors have read and agreed to the published version of the manuscript.

Funding: This research received no external funding.

Institutional Review Board Statement: Not applicable.

Informed Consent Statement: Not applicable.

Data Availability Statement: The data used to support the findings of this study are included within the article.

Conflicts of Interest: The authors declare no conflict of interest.

\section{References}

1. de Azeredo, H.M.C.; Otoni, C.G.; de Assis, O.B.G.; Forato, L.A.; Bernardes-Filho, R. In a nutshell: Prospects and challenges on coatings for edible kernels. J. Sci. Food Agric. 2020, 100, 2321-2326. [CrossRef]

2. Bonilla, J.; Poloni, T.; Sobral, P.J.A. Active edible coatings with Boldo extract added and their application on nut products: Reducing the oxidative rancidity rate. Int. J. Food Sci. Technol. 2018, 53, 700-708. [CrossRef]

3. Galus, S.; Kibar, E.A.A.; Gniewosz, M.; Kraśniewska, K. Novel materials in the preparation of edible films and coatings-A review. Coatings 2020, 10, 674. [CrossRef]

4. Sahraee, S.; Milani, J.M.; Regenstein, J.M.; Kafil, H.S. Protection of foods against oxidative deterioration using edible films and coatings: A review. Food Biosci. 2019, 32, 100451. [CrossRef]

5. Díaz-Montes, E.; Castro-Muñoz, R. Edible films and coatings as food-quality preservers: An overview. Foods 2021, 10, 249. [CrossRef] [PubMed]

6. Leichtfried, D.; Krist, S.; Puchinger, L.; Messner, K.; Buchbauer, G. Investigations of the natural microflora of poppy seeds (Papaver somniferum) and hazelnut kernels (Corylus avellana) including microbiological decomposition. Eur. Food Res. Technol. 2004, 219, S282-S285. [CrossRef]

7. Barreira, J.C.M.; Nunes, M.A.; da Silva, B.V.; Pimentel, F.B.; Costa, A.S.G.; Alvarez-Ortí, M.; Pardo, J.E.; Oliveira, M.B.P.P. Almond cold-pressed oil by-product as ingredient for cookies with potential health benefits: Chemical and sen-sory evaluation. Food Sci. Hum. Wellness 2019, 8, 292-298. [CrossRef] 
8. Contador, L.; Robles, B.; Shinya, P.; Medel, M.; Pinto, C.; Reginato, G.; Infante, R. Characterization of texture attributes of raw almond using a trained sensory panel. Fruits 2015, 70, 231-237. [CrossRef]

9. Franklin, L.M.; Mitchell, A.E. Review of the sensory and chemical characteristics of almond (Prunus dulcis) flavor. J. Agric. Food Chem. 2019, 67, 2743-2753. [CrossRef]

10. Sottile, F.; Massaglia, S.; Peano, C. Ecological and economic indicators for the evaluation of almond (Prunus dulcis L.) orchard renewal in sicily. Agriculture 2020, 10, 301. [CrossRef]

11. Marvinney, E.; Kendall, A. A scalable and spatiotemporally resolved agricultural life cycle assessment of California al-monds. Int. J. Life Cycle Assess. 2021, 1-23. [CrossRef]

12. Bartzas, G.; Komnitsas, K. Life cycle analysis of pistachio production in Greece. Sci. Total Environ. 2017, 595, 13-24. [CrossRef]

13. Casas-Agustench, P.; Salas-Huetos, A.; Salas-Salvadó, J. Mediterranean nuts: Origins, ancient medicinal benefits and symbolism. Public Health Nutr. 2011, 14, 2296-2301. [CrossRef]

14. Özcan, M.M.; Al Juhaimi, F.; Ghafoor, K.; Babiker, E.E.; Özcan, M.M. Characterization of physico-chemical and bioactive properties of oils of some important almond cultivars by cold press and soxhlet extraction. J. Food Sci. Technol. 2020, 57, 955-961. [CrossRef]

15. Barreca, D.; Nabavi, S.M.; Sureda, A.; Rasekhian, M.; Raciti, R.; Silva, A.S.; Annunziata, G.; Arnone, A.; Tenore, G.C.; Süntar, I.; et al. Almonds (Prunus Dulcis Mill. D. A. Webb): A source of nutrients and health-promoting compounds. Nutrients 2020, 12, 672. [CrossRef]

16. Yada, S.; Lapsley, K.; Huang, G. A review of composition studies of cultivated almonds: Macronutrients and micronutrients. J. Food Compos. Anal. 2011, 24, 469-480. [CrossRef]

17. Milbury, P.E.; Chen, C.-Y.; Dolnikowski, A.G.G.; Blumberg, J.B. Determination of flavonoids and phenolics and their distribution in almonds. J. Agric. Food Chem. 2006, 54, 5027-5033. [CrossRef]

18. Blomhoff, R.; Carlsen, M.H.; Andersen, L.F.; Jacobs, D.R. Health benefits of nuts: Potential role of antioxidants. Br. J. Nutr. 2006, 96, S52-S60. [CrossRef]

19. Özcan, M.M.; Ünver, A.; Erkan, E.; Arslan, D. Characteristics of some almond kernel and oils. Sci. Hortic. 2011, 127, 330-333. [CrossRef]

20. Roncero, J.M.; Álvarez-Ortí, M.; Pardo-Giménez, A.; Rabadán, A.; Pardo, J.E. Review about non-lipid components and minor fat-soluble bioactive compounds of almond kernel. Foods 2020, 9, 1646. [CrossRef]

21. Berryman, C.E.; Preston, A.G.; Karmally, W.; Deckelbaum, R.J.; Kris-Etherton, P.M. Effects of almond consumption on the reduction of LDL-cholesterol: A discussion of potential mechanisms and future research directions. Nutr. Rev. 2011, 69, 171-185. [CrossRef] [PubMed]

22. Roncero, J.M.; Álvarez-Ortí, M.; Pardo-Giménez, A.; Gómez, R.; Rabadán, A.; Pardo, J.E. Almond virgin oil: Parameters of regulated physicochemical quality and stability. Riv. Ital. Sostanze Grasse 2016, 93, 237-243.

23. Oliveira, I.; Meyer, A.S.; Afonso, S.; Aires, A.; Goufo, P.; Trindade, H.; Gonçalves, B. Phenolic and fatty acid profiles, $\alpha$-tocopherol and sucrose contents, and antioxidant capacities of understudied Portuguese almond cultivars. J. Food Biochem. 2019, 43 , e12887. [CrossRef] [PubMed]

24. Barreira, J.C.; Casal, S.; Ferreira, I.C.; Peres, A.M.; Pereira, J.A.; Oliveira, M.B.P. Supervised chemical pattern recognition in almond (Prunus dulcis) portuguese PDO cultivars: PCA- and LDA-based triennial study. J. Agric. Food Chem. 2012, 60, 9697-9704. [CrossRef]

25. Csakvari, A.C.; Lupitu, A.; Bungău, S.; Gîtea, M.A.; Gîtea, D.; Ţiţ, D.M.; Copolovici, D. Fatty acids profile and antioxi-dant activity of almond oils obtained from six Romanian varieties. Farmacia 2019, 67, 882-887. [CrossRef]

26. Maestri, D.; Martínez, M.; Bodoira, R.; Rossi, Y.; Oviedo, A.; Pierantozzi, P.; Torres, M. Variability in almond oil chemical traits from traditional cultivars and native genetic resources from Argentina. Food Chem. 2015, 170, 55-61. [CrossRef]

27. Ojeda-Amador, R.M.; Fregapane, G.; Salvador, M.D. Chemical characterization of virgin almond and hazelnut oils and their by-products. Eur. J. Lipid Sci. Technol. 2019, 121, 1-10. [CrossRef]

28. Rabadán, A.; Álvarez-Ortí, M.; Martínez, E.; Pardo-Giménez, A.; Zied, D.C.; Pardo, J.E. Effect of replacing traditional ingredients for oils and flours from nuts and seeds on the characteristics and consumer preferences of lamb meat burgers. LWT 2021, 136, 110307. [CrossRef]

29. Padehban, L.; Ansari, S.; Koshani, R. Effect of packaging method, temperature and storage period on physicochemical and sensory properties of wild almond kernel. J. Food Sci. Technol. 2018, 55, 3408-3416. [CrossRef]

30. Larrauri, M.; Demaría, M.G.; Ryan, L.C.; Asensio, C.M.; Grosso, N.R.; Nepote, V. Chemical and sensory quality preservation incoated almonds with the addition of antioxidants. J. Food Sci. 2016, 81, S208-S215. [CrossRef]

31. Atarés, L.; Pérez-Masiá, R.; Chiralt, A. The role of some antioxidants in the HPMC film properties and lipid protection in coated toasted almonds. J. Food Eng. 2011, 104, 649-656. [CrossRef]

32. Haq, M.A.; Alam, M.J.; Hasnain, A. Gum Cordia: A novel edible coating to increase the shelf life of Chilgoza (Pinus gerardiana). LWT-Food Sci. Technol. 2016, 50, 306-311. [CrossRef]

33. Chinma, C.; Ariahu, C.; Abu, J. Shelf life extension of toastedgroundnuts through the application of cassava starch and soyproteinbased edible coating. Niger. Food J. 2014, 32, 133-138. [CrossRef]

34. Nawab, A.; Alam, F.; Haq, M.A.; Lutfi, Z.; Hasnain, A. Effect of mango kernel starch coatings on the shelflife of almond (Prunus dulcis) kernels. J. Food Process. Preserv. 2018, 42, e13449. [CrossRef] 
35. Rusu, A.V.; Criste, F.L.; Mierliţă, D.; Socol, C.T.; Trif, M. Formulation of lipoprotein microencapsulated beadlets by ionic complexes in algae-based carbohydrates. Coatings 2020, 10, 302. [CrossRef]

36. Dietrich, T.; Velasco, M.V.; Echeverría, P.; Pop, B.; Rusu, A. Crop and plant biomass as valuable material for BBB. Alternatives for valorization of green wastes. In Biotransformation of Agricultural Waste and By-Products: The Food, Feed, Fibre, Fuel (4F) Economy; Elsevier: San Diego, CA, USA, 2016.

37. Dabos, K.; Sfika, E.; Vlatta, L.; Giannikopoulos, G. The effect of mastic gum on Helicobacter pylori: A randomized pilot study. Phytomedicine 2010, 17, 296-299. [CrossRef]

38. Biria, M.; Eslami, G.; Taghipour, E.; Baghban, A.A. Effects of three mastic gums on the number of mutans strep-tococci, lactobacilli and $\mathrm{PH}$ of the saliva. J. Dent. 2014, 11, 672-679.

39. Koychev, S.; Dommisch, H.; Chen, H.; Pischon, N. Antimicrobial effects of mastic extract against oral and periodontal pathogens. J. Periodontol. 2017, 88, 511-517. [CrossRef]

40. Ierapetritis, D. The geography of the chios mastic trade from the 17th through to the 19th Century. Ethnobot. Res. Appl. 2010, 8 , 153-167. [CrossRef]

41. Aksoy, A.; Duran, N.; Köksal, F. In vitro and in vivo antimicrobial effects of mastic chewing gum against Streptococcus mutans and mutans streptococci. Arch. Oral Biol. 2006, 51, 476-481. [CrossRef]

42. Liang, P.-S.; Slaughter, D.C.; Ortega-Beltran, A.; Michailides, T.J. Detection of fungal infection in almond kernels using nearinfrared reflectance spectroscopy. Biosyst. Eng. 2015, 137, 64-72. [CrossRef]

43. Alsuhaibani, A.M.A. Effects of storage periods and temperature on mold prevalence and aflatoxin contamination in nuts. Pak. J. Nutr. 2018, 17, 219-227. [CrossRef]

44. AOAC. Official Methods of Analysis. Association of Official Analytical Chemists; AOAC: Washington, DC, USA, 2005.

45. Prgomet, I.; Gonçalves, B.; Domínguez-Perles, R.; Pascual-Seva, N.; Barros, A.I. Valorization challenges to Al-mond residues: Phytochemical composition and functional application. Molecules 2017, 22, 1774. [CrossRef] [PubMed]

46. Bourtoom, T.; Chinnan, M.S. Preparation and properties of rice starch-chitosan blend biodegradable film. LWT-Food Sci. Technol. 2018, 41, 1633-1641. [CrossRef]

47. Tavakolipour, H.; Javanmard Dakheli, M.; Zirjany, L. Inhibitory effect of coating pistachio kernel based in whey pro-tein concentrate (WPC) and thyme essential oil on aflatoxin production. Food Sci. Technol. 2011, 2, 53-63.

48. AOAC. Official Methods of Analysis, 18th ed.; Association of Official Analytical Chemists: Gaithersburg, MD, USA, 2007.

49. AACC. Approved Methods of the American Association of the Cereal Chemist, 10th ed.; AACC: Washington, DC, USA, 2000.

50. Trezza, T.A.; Krochta, J.M. Color stability of edible coatings during prolonged storage. J. Food Sci. 2000, 65, 1166-1169. [CrossRef]

51. American Oil Chemists' Society (AOCS). Officialmethod for Determining Peroxide Value Acetic Ac-Id-Chloroform; Cd 8-53; AOCS: Champaign, IL, USA, 2003.

52. Firestone, D. (Ed.) Official Methods and Recommended Practices of the AOCS; The American Oil Chemists Society: Champaign, IL, USA, 2005.

53. Peter, W.; Wade, Y.; Nasson-R, M. Effects of sonication and edible coating containing rosemary and tea extracts on reduction of peanut lipid oxidative rancidity. Food Bioprocess Technol. 2011, 4, 107-115.

54. Parreidt, T.S.; Lindner, M.; Rothkopf, I.; Schmid, M.; Müller, K. The development of a uniform alginate-based coating for cantaloupe and strawberries and the characterization of water barrier properties. Foods 2019, 8, 203. [CrossRef]

55. Grilo, F.S.; Srisaard, Y.; Wang, S.C. Prediction of walnut deterioration using kernel oxidative stability. Foods 2020, 9, 1207. [CrossRef]

56. Reveros, C.G.; Mestrallet, M.G.; Quiroga, P.R.; Nepote, V.; Grosso, N.R. Preserving sensory attributes of roasted pea-nuts using edible coatings. Int. J. Food Sci. Tech. 2013, 48, 850-859. [CrossRef]

57. Ribeiro, C.; Vicente, A.A.; Teixeira, J.A.; Miranda, C. Optimization of edible coating composition to retard strawberry fruit senescence. Postharvest Biol. Technol. 2007, 44, 63-70. [CrossRef]

58. Alasalvar, C.; Shahid, F.; Ohshima Wanasundara, U.; Yurttas, C.T. Turkish tombul hazelnut (corylus avellana L.). Lipid characteristics and oxidative stability. J. Agric. Food Chem. 2003, 51, 3797-3805. [CrossRef]

59. Gurses, M. Mycroflora and aflatoxin content of hazelnuts, walnuts, peanuts, almonds and chickpeas (leblebi) sold in Turkey. Int. J. Food Properrties 2006, 9, 395-399. [CrossRef]

60. Sorkheh, K.; Kiani, S.; Sofo, A. Wild almond (Prunus scoparia L.) as potential oilseed resource for the future: Studies on the variability of its oil content and composition. Food Chem. 2016, 212, 58-64. [CrossRef]

61. Moayedi, A.; Rezaei, K.; Moini, S.; Keshavarz, B. Chemical compositions of oils from several wild almond species. J. Am. Oil Chem. Soc. 2010, 88, 503-508. [CrossRef]

62. Mexis, S.F.; Badeka, A.V.; Kontominas, M.G. Quality evaluation of raw ground almond kernels (Prunus dulcis): Effect of active and modified atmosphere packaging, container oxygen barrier and storage conditions. Innov. Food Sci. Emerg. Technol. 2009, 10, 580-589. [CrossRef]

63. Sandhya. Modified atmosphere packaging of fresh produce: Current status and future needs. LWT Food Sci. Technol. 2010, 43, 381-392. [CrossRef]

64. Carrasco-Del Amor, A.M.; Aguayo, E.; Collado-González, J.; Guy, A.; Galano, J.-M.; Durand, T.; Gil-Izquierdo, Á. Impact of packaging atmosphere, storage and processing conditions on the generation of phytoprostanes as quality processing compounds in almond kernels. Food Chem. 2016, 211, 869-875. [CrossRef] 
65. Mexis, S.F.; Kontominas, M.G. Effect of oxygen absorber, nitrogen flushing, packaging material oxygen transmission rate and storage conditions on quality retention of raw whole unpeeled almond kernels (Prunus dulcis). LWT-Food Sci. Technol. 2010, 43, 1-11. [CrossRef]

66. Mexis, S.F.; Riganakos, K.A.; Kontominas, M.G. Effect of irradiation, active and modified atmosphere packaging, con-tainer oxygen barrier and storage conditions on the physicochemical and sensory properties of raw unpeeled almond kernels (Prunus dulcis). J. Sci. Food Agric. 2011, 91, 634-649. [CrossRef]

67. Ghirardello, D.; Contessa, C.; Valentini, N.; Zeppa, G.; Rolle, L.; Gerbi, V.; Botta, R. Effect of storage conditions on chem-ical and physical characteristics of hazelnut (Corylus avellana L.) Postharvest. Biol. Technol. 2013, 81, 37-43. [CrossRef]

68. Kang, H.J.; Kim, S.J.; You, Y.S.; Lacroix, M.; Han, J. Inhibitory effect of soy protein coating formulations on walnut (Juglans regia L.) kernels against lipid oxidation. LWT-Food Sci. Technol. 2013, 51, 393-396. [CrossRef]

69. Rossi-Márquez, G.; Helguera, M.; Briones, M.; Dávalos-Saucedo, C.A.; Di Pierro, P. Edible Coating from Enzymatically Reticulated Whey Protein-Pectin to Improve Shelf Life of Roasted Peanuts. Coatings 2021, 11, 329. [CrossRef]

70. Trif, M.; Vodnar, D.C.; Mitrea, L.; Rusu, A.V.; Socol, C.T. Design and development of oleoresins rich in carotenoids coated microbeads. Coatings 2019, 9, 235. [CrossRef]

71. Creedon, A.C.; Hung, E.S.; Berry, S.E.; Whelan, K. Nuts and their effect on gut microbiota, gut function and symptoms in adults: A systematic review and meta-analysis of randomised controlled trials. Nutrients 2020, 12, 2347. [CrossRef]

72. Forstner, S.; Rusu, A. Development of personalised food for the nutrition of elderly consumers. In Know Your Food: Food Ethics and Innovation; Academic Publishers: Wageningen, The Netherlands, 2015; pp. 24-27.

73. Siddiqui, I.; Husain, Q.; Azam, A. Exploring the antioxidant effects of peptides from almond proteins using PAni-Ag-GONC conjugated trypsin by improving enzyme stability \& applications. Int. J. Biol. Macromol. 2020, 158, 150-158. [CrossRef]

74. Rusu, A.V.; Penedo, B.A.; Schwarze, A.-K.; Trif, M. The influence of Candida spp. in intestinal microbiota; diet therapy, the emerging conditions related to candida in athletes and elderly people. In Update in Geriatrics, Somchai Amornyotin; IntechOpen: London, UK, 2021. [CrossRef]

75. Zheng, Z.; Saghaian, S.; Reed, M. Factors affecting the export demand for US pistachios. Int. Food Agribus. Manag. Rev. 2012, 15, 139-154.

76. Rusu, A.; Randriambelonoro, M.; Perrin, C.; Valk, C.; Álvarez, B.; Schwarze, A.-K. Aspects Influencing Food Intake and Approaches towards Personalising Nutrition in the Elderly. J. Popul. Ageing 2020, 13, 239-256. [CrossRef]

77. Xiong, B. Food safety and food imports in Europe: The risk of aflatoxins in pistachios. Int. Food Agribus. Manag. Rev. 2016, 20, 129-141. [CrossRef]

78. Rahimi, R.; Shams-Ardekani, M.R.; Abdollahi, M. A review of the efficacy of traditional Iranian medicine for inflam-matory bowel disease. World J. Gastroenterol. 2010, 16, 4504. [CrossRef] [PubMed]

79. Molamohammadi, H.; Pakkish, Z.; Akhavan, H.-R.; Saffari, V.R. Effect of salicylic acid incorporated chitosan coating on shelf life extension of fresh in-hull pistachio fruit. Food Bioprocess Technol. 2020, 13, 121-131. [CrossRef]

80. Ebrahimzadeh, A.; Pirzad, F.; Tahanian, H.; Aghdam, M.S. Influence of gum arabic enriched with GABA coating on oxidative damage of walnut kernels. Food Technol. Biotechnol. 2019, 57, 554-560. [CrossRef]

81. Martín, M.P.; Riveros, C.G.; Paredes, A.J.; Allemandi, D.A.; Nepote, V.; Grosso, N.R. A Natural Peanut Edible Coating Enhances the Chemical and Sensory Stability of Roasted Peanuts. J. Food Sci. 2019, 84, 1529-1537. [CrossRef]

82. Raisi, M.; Ghorbani, M.; Mahoonak, A.S.; Kashaninejad, M.; Hosseini, H. Effect of storage atmosphere and temperature on the oxidative stability of almond kernels during long term storage. J. Stored Prod. Res. 2015, 62, 16-21. [CrossRef]

83. Sabaghi, M.; Maghsoudlou, Y.; Khomeiri, M.; Ziaiifar, A.M. Active edible coating from chitosan incorporating green tea extract as an antioxidant and antifungal on fresh walnut kernel. Postharvest Biol. Technol. 2015, 110, 224-228. [CrossRef]

84. Fukazawa, T.; Smyrniodis, I.; Konishi, M.; Takahashi, M.; Kim, H.; Numao, S.; Sakamoto, S. Comparative study between Western and Asian pharmaceutical plants: The efficacy of the Greek mastic and the Japanese ume. Deltos 2014, 43, 31-38.

85. Fukazawa, T.; Smyrnioudis, I.; Konishi, M.; Takahashi, M.; Kim, H.K.; Nishimaki, M.; Xiang, M.; Sakamoto, S. Effects of Chios mastic gum and exercise on physical characteristics, blood lipid markers, insulin resistance, and hepatic function in healthy Japanese men. Food Sci. Biotechnol. 2018, 27, 773-780. [CrossRef] [PubMed] 